\title{
ТРАДИЦИИ ХРИСТИАНСКОЙ АРХИТЕКТУРЫ \\ КАК ИНСТРУМЕНТ СОХРАНЕНИЯ ИСТОРИЧЕСКОЙ ПАМЯТИ (НА ПРИМЕРЕ ДЕРЕВЯННОГО ЗОДЧЕСТВА)
}

\author{
С. А. ПИЛЯК \\ Музей «Смоленская крепостная стена», г. Смоленск, Россия
}

Современное культовое строительство, в особенности православное, на протяжении сравнительно недавнего времени приобрело практически массовый характер. Повсеместно, и в крупных городах, и в сравнительно небольших населенных пунктах появляются новые храмы и другие сооружения культового характера. Современные архитекторы, проектируя православные храмы, как правило, стоят перед непростым выбором типа и облика сооружения. Современная архитектура культовых зданий, по ряду причин не имеющая приемлемых образцов, выработанных нынешними практикующими зодчими, опирается на опыт культовой архитектуры предшествующих эпох. Многовековая история русской архитектуры при этом предлагает большое количество ярких сооружений, составивших славу как русских городов, так и русских зодчих. Естественно, что зачастую при создании современных храмов архитекторы ориентируются как на конкретные сооружения, иногда практически полностью копируя их облик в новых храмах, так и на определенные исторические эпохи и стили, комбинируя черты разных сооружений в заново возводимом объекте. В некоторых случаях обращение архитекторов к архитектуре минувших эпох позволяет обратить внимание на характерные региональные особенности и даже в определенной степени продлить их бытование. В этом случае современный храм является не только зданием для богослужений, но и знаком присутствия и инструментом ретрансляции храмостроительной традиции, что вполне соответствует понятию, введенному Августином Блаженным: «Знак вообще есть предмет, который сверх собственного вида или формы, действующей на наши чувства, возбуждает в уме нашем представление других известных предметов» [1, с. 67].

Автором проведена работа по исследованию региональных храмостроительных традиций [3]. По итогам проведенного анализа и систематизации определено, что ключевой региональной композиционной особенностью, в различной степени отразившейся на облике подавляющего количества костромских деревянных храмов, является контрастное соотношение между массивным рубленым основанием, занимающим до 2/3 высоты храма, и миниатюрным завершением. К общероссийским тенденциям, объединяющим всю территорию Центральной России, является идея ярусности, по-разному представленная практически в каждой костромской деревянной культовой постройке. Диапазон форм невероятно широк - от нескольких крупных рубленых ярусов, составляющих основу облика памятника и строящих его силуэт, до каркасных поздних решений.

Особую группу культовых сооружений составляют объекты, архитектура которых ориентируется на конкретные памятники деревянного зодчества. В 1996 году в селе НиколаДор (Палкино) Галичского района к востоку от существовавшей Николаевской церкви построен новый деревянный храм, освященный во имя прп. Серафима Саровского. Церковь является одним из распространенных примеров заимствования архитектуры церкви из села Фоминское Костромского района, в настоящее время являющейся одним из экспонатов Костромского музея деревянного зодчества. За исключением отдельных пропорций, некоторых конструктивных решений, металлической кровли, храм является точной копией музеефицированного объекта. 
Храмовый комплекс в урочище Введенское-Борисовка Наро-Фоминского района Московской области представляет собой интересный пример, не связанный с Костромской областью географически, но в типологическом плане имеющий весьма четкие параллели с рассматриваемым регионом. Комплекс, состоящий исключительно из сооружений решенных в стилистике русского деревянного зодчества, включает три церкви и звонницу. Наиболее крупный храм был построен по образцу с известнейшим деревянным храмом Костромской области - клетской Спасо-Преображенской церковью на сваях из села Спас-Вежи. Повторение данного памятника в первую очередь было связано с тем, что в 2002 году он был утрачен. Архитектура другого храма сориентирована на утраченную в первой половине XX века Васильевскую церковь в селе Шохна Нерехтского уезда Костромской губернии. Церковь, построенная в XVII столетии [4], является редким сооружением, облик которого стал следствием обмирщения архитектуры культовых зданий в данный период времени.

Подобное воссоздание храмов с учетом использования сооружений по первоначальному назначению является перспективным направлением, позволяющим в полной мере транслировать характерные региональные черты народной архитектуры с учетом ее высокой историко-культурной значимости.

Выразительный храм во имя Покрова Божией Матери, к настоящему моменту утраченный в пожаре, был поставлен в черте поселка Островское Костромской области. Крещатый храм, прирубы которого увенчаны бочками, завершен высоким восьмериком под шатром. Интересный пример культового здания, очевидно, сориентирован на известный вологодский пример - Успенскую церковь Свято-Успенского Александро-Куштского монастыря. Храм представляет собой пример нового строительства без учета региональных архитектурных традиций.

Таким образом, по итогам проведенного анализа выявлены направления современного деревянного храмостроительства, определяющих преемственность в развитии региональных архитектурных традиций культового деревянного зодчества:

- строительство храмов «по образцу», предусматривающее повторение известного произведения архитектуры;

- строительство современных храмов с ориентацией на костромские региональные особенности; особенностей;

строительство современных храмов без учета костромских региональных

- $\quad$ строительство современных храмов с учетом региональных особенностей иной историко-культурной зоны.

Сейчас внимание профессионального сообщества во многом приковано к расчету процента воссоздаваемых конструкций. Однако точные расчеты в сфере культурного наследия, воспринимаемого всегда субъективно, далеко не всегда, при наличии всех возможных современных технологий, позволяют достичь нужного эффекта. К тому же само отношение к подлиннику в настоящее время отличается известной противоречивостью: «Во второй половине XX века началось размывание ценностных критериев в культуре, связанное сначала с практикой репродуцирования произведений искусства (от чего теряется представление о ценности подлинника), позднее - с распространением идеи плюрализма» [5]. Вопрос воссоздания памятников архитектуры остается открытым. Тем не менее, общее мнение по этому вопросу, выраженное академиком И. Лежавой, существует: «сотни замков, крепостей, соборов - фактически «новодел». Думаю, ничего плохого не будет в том, что появятся новые «муляжи», которые всего лишь напомнят прошлое» [2, с. 26]. 

Литература
1. Августин Блаженный. Христианская наука, или Основания св. герменевтики и
церковного красноречия. - Киев, 1835.

2. Лежава, И. Г. Будущее городов // Фундаментальные исследования РААСН по научному обеспечению развития архитектуры, градостроительства и строительной отрасли Российской Федерации в 2009 году: науч. тр. РААСН: в 2 т. / РААСН, Иван. гос. архит.строит. ун-т; под ред. А. П. Кудрявцева [и др.]. - М.-Иваново, 2010. - Т. 1. - С. 24-32.

3. Пиляк, С. А. Композиционные особенности костромского деревянного культового зодчества XVII - начала XX вв. : диссертация на соискание ученой степени кандидата архитектуры по специальности 05.23.20. Теория и история архитектуры, реставрация и реконструкция историко-культурного наследия. - Москва, 2019. - 353 с.

4. Пиляк, С. А. К вопросу о датировке деревянного храма во имя Святителей Василия Великого и Николая Чудотворца в селе Шохна / С. А. Пиляк // Деревянное зодчество : сборник научных статей / НИИ теории и истории архитектуры и градостроительства. Москва ; Санкт-Петербург : Коло, 2015. - Вып. 4. Новые материалы и открытия. C. 197-207.

5. Щенков, А. С. Архитектурно-градостроительное наследие в научных исследованиях РАACH // Фундаментальные исследования РААСН по научному обеспечению развития архитектуры, градостроительства и строительной отрасли Российской Федерации в 2009 году: науч. тр. РААСН: в 2 т. / РААСН, Иван. гос. архит.-строит. ун-т; под ред. А. П. Кудрявцева [и др.]. - М. - Иваново, 2010. - Т. 1. - С. 50-53.

Расширение присутствия любой религии неразрывно связно с наличием и распространенностью ее зримых символов в пространстве, окружающем верующих. В связи с необходимостью создания новых православных деревянных храмов современные зодчие зачастую копируют отдельные мотивы или композицию памятников православного храмового зодчества прошлых эпох, что отчасти способствует сохранению оригинальных архитектурных творений. Данная статья подготовлена на материалах Костромской области.

The expansion of the presence of any religion is inextricably linked to the presence and prevalence of its visible symbols in the space surrounding believers. Due to the need to create new Orthodox wooden churches, modern architects often copy individual motifs or compositions of monuments of Orthodox temple architecture of past eras, which partly contributes to the preservation of original architectural creations. This article is based on materials from the Kostroma region. 